Int. J. Odontostomat.,

15(1):59-66, 2021.

\title{
COVID-19 Safety Protocols in Dental Clinical Education in the Second Wave
}

\author{
Protocolos anti COVID-19 en la Educación Clínica \\ de Odontología durante la Segunda Ola
}

\begin{abstract}
Ana Leticia Lenguas Silva1; Maria Victoria Mateos Moreno1; Germán García Vicent'; Marta Lamas Oliveira1; José Francisco Martín Morales ${ }^{1}$; Javier Valdepeñas Morales ${ }^{2}$ \& Maria Rosario Garcillán Izquierdo ${ }^{3}$
\end{abstract}

\begin{abstract}
LENGUAS, S. A. L.; MATEOS, M. M. V.; GARCÍA, V. G.; LAMAS, O. M.; MARTÍN, M. J. F. ; VALDEPEÑAS, M. J. \& GARCILLÁN, I. M. R. COVID-19 safety protocols in dental clinical education in the second wave. Int. J. Odontostomat., 15(1):59-66, 2021.
\end{abstract}

ABSTRACT: This second wave of the COVID-19 pandemic has led to the development of strategies for guaranteeing clinical teaching in dental schools and adapt it to this new epidemiological situation protecting the health of all staff, students, patients and persons accompanying them. We reviewed a total of 51 documents, including articles and guidelines or recommendations issued by dental schools, scientific societies and other institutions, in order to take stock of the current evidence available about the impact of the COVID-19 pandemic on dental schools. We describe a series of measures to implement in semi-critical and critical areas of dental schools to guarantee the safety of all and the continuity of the clinical training of students. These include: mobility circuits, appropriate distancing, patient scheduling, telephone triage, personal protective equipments, measures to reduce viral transmission by air ventilation and several other actions specific to low or high aerosol generating by treatments. Dental schools must be prepared and implement the necessary measures according to the level of infection risk during face-to-face activities, especially in clinics, which provide essential formation and impossible to acquire online. Dental schools should focus on prioritizing preventive and minimally invasive dentistry minimizing aerosol generating procedures whenever possible. More than ever, the international cooperation among universities for the elaboration of protocols is essential. These protocols must ensure the health of everyone in this new second wave of the pandemic and in possible future epidemiological scenarios.

KEY WORDS: dental schools, dental education, prevention, COVID-19, SARS-CoV2.

\section{INTRODUCTION}

Today we are in a critical epidemiological moment because the COVID pandemic continues to rise across Spain, and dental education must go on. Thus, we must develop protocols to adapt our clinical teaching to this second wave.

Nowadays it is known that the SARS-CoV-2 virus is mainly transmitted by the respiratory route (respiratory droplets and aerosols) and by direct contact with contaminated surfaces and subsequent contact with nasal, oral or ocular mucosa (Whitworth, 2020), and that asymptomatic and incubation patients (presymptomatic) have the ability to transmit the virus before any symptoms are apparent (Izzetti et al., 2020; Rothe et al., 2020).

The angiotensin II converting enzyme (ACE2) is probably the cellular receptor for SARS-CoV-2 (Xu et al., 2020). ACE2 receptors are highly expressed in the oral cavity and are highly present in epithelial cells, so the mucosa of the oral cavity may be a potential high-risk route for SARS-CoV-2 infection.

${ }^{1}$ Assistant professor of the Department of Dental Clinical Specialties, School of Dentistry, Madrid Complutense University, Madrid, Spain.

${ }^{2}$ Honorary Collaborating Proffesor of Department of Dental Clinical Specialties, School of Dentistry, Madrid Complutense University, Madrid, Spain.

${ }^{3}$ Vice-Dean and Tenured Assistant Professor of the Department of Dental Clinical Specialties, School of Dentistry, Madrid Complutense University, Madrid, Spain. 
Dental care settings invariably carry the risk of SARS-CoV-2 infection due to the proximity of the procedures, which are performed within $45 \mathrm{~cm}$ from patients and with exposure to saliva, blood, and other body fluids from the nasal and oropharyngeal environment, together with the handling of instruments and the possibility of direct transmission by contact with contaminated surfaces (Meng et al., 2020; Peng et al., 2020). The Occupational Safety and Health Administration of the United States Department of Labor, 2020) classified dentists as very high risk due to the potential for exposure to the coronavirus through aerosol-generating procedures.

Dental schools have different profiles of workers, which include administrative, management and teaching staff and researchers. In our previous article "New rules for teaching in dental schools in the COVID 19 era" (in press) we describe the strategies developed for adapting dental education to the new situation.

In this current paper we report the research of the evidence on clinical protocols aimed at guaranteeing the safety of all (staff, students, faculty and patients) while ensuring continuity in the quality training of students. These protocols must ensure the health of everyone in this pandemic and in possible future scenarios.

\section{MATERIAL AND METHOD}

The bibliographic search has been carried out in MEDLINE (via Pubmed database) using the following MeSH terms: (dental schools OR dental education OR prevention) AND (COVID-19 OR SARS-CoV-2). In addition, web pages of international official organizations, national guides, scientific societies, dental schools and other institutions of dental education worldwide, were revised. We found 51 articles, most of them observational and based on the expert review of the evidence currently available, with very few experimental articles.

\section{RESULTS AND DISCUSSION}

a) Plan for progressive adaptation to clinical classroom teaching: It is essential to define which will be the semi-critical or critical areas or elements in the dental school. In each of them, a series of specific measures will be established and the mobility circuits will be determined (University of Glasgow, 2020).
Semicritical elements or areas: reception, waiting room, access corridors to differentiated entrance and exit cabinets, offices, meeting room, toilets, cafeteria. This space will be more used by administrative staff. General actions:

- Use zonal barrier methods (methacrylate partitions) or personal barrier methods (use of surgical mask) (Pastor Ramos et al., 2020).

- Do not let accumulate a large number of people in the waiting room: use at most a third of the available capacity and always separate the patients by at least one seat (measuring at least 1.5 meters). Establish entry and exit points for patients.

- Remove unnecessary furniture and decorative objects, brochures or magazines available to patients. - Place informative posters (laminated to allow cleaning) on the wall. (University of Glasgow).

- Ask the patient to refrain from moving around the clinic and remain seated.

- Perform timely aeration and disinfection of frequently touched surfaces of common administrative spaces (computer keyboards, touchscreens, telephones, remote controls, door knobs, switches, tables, armrests of armchairs) and toilets (toilet, faucets, doorknobs, switches) (Henwood, 2020). Patients are forbidden to brush their teeth in the toilets before appointments.

Critical elements or areas: dental cabinet, cleaning room and instrument sterilization. These spaces will be more used by clinical staff (Facultad de Odontología, Universidad Complutense de Madrid, 2020). General actions:

- Determine the number of patients that can be seen per day, according to space availability and ventilation times.

- The entrance to the clinic will be by groups of two teammates and the clinical work will preferably also be carried out in pairs.

- Students must not coincide with members of other teams in radiology areas (directed shifts). These areas will be decontaminated with ultraviolet light. Develop a system of rotation of students by the radiology service to carry out the $\mathrm{X}$-rays that are needed every day.

- Initially, four patients per box will be treated each day for 6 hours and the number will be increased as prevention measures are controlled.

- An auxiliary student will be in charge of calling the patient. The student performing clinical work should not move out of the box. 
- Work in the clinics is restricted to two dental chairs for each group of four chairs.

- Hand hygiene will be carried out: before putting on the PPE, before and after contact with patients, after contact with contaminated surfaces or equipment and after taking off the PPE (personal protective equipment (Peng et al.).

- Hair must be worn up. Earrings, rings, bracelets, etc. that make it difficult to place the PPE or to perform hand hygiene must be removed. Some protocols recommend shaving the face completely (the beard makes it difficult to adapt self-filtering masks) and keeping the nails short (Peditto et al., 2020).

- The number of people participating in a clinical session should be reduced to a minimum, preferably a team of two students formed by operator and clinical of assistant. In some cases, the attendance of an additional assistant outside the surgical field and as a liaison may be advisable.

- Limit the number of appointments for each patient, trying to carry out various treatments every time they go to the clinic in order to minimize risks and optimize the use of PPE (Peditto et al.).

- It is recommended to rinse with povidone iodine 0.2 $\%$, hydrogen peroxide $1 \%$ or cetylpyridinium chloride $0.07 \%$ or $0.05 \%$, prior to exploration or oral treatment (Herrera et al., 2020; Izzetti et al.).

- Limit the field of work as much as possible, using surgical field isolation techniques; use of the rubber dam is recommended (98\% reduction of aerosol) (Cochran et al., 1989; Tag El Din \& Ghoname, 1997; Prati et al., 2020).

- Use high speed handpieces only if necessary; if possible, remove caries manually with a spoon or manual instruments or at low speed (always preferable) and always with an anti-reflux device (National Health Service, 2020).

- Encourage the use of high-power aspiration ejectors (high-volume aspiration cannulas $16 \mathrm{~mm}$ in diameter) to minimize the production of aerosols (Dental Schools Council, 2020; Jacks, 2002; King et al., 1997).

- Work four-handedly as much as possible.

- Avoid procedures that induce cough or gag reflexes. Perform preferably extra-oral radiographs

- Use absorbable suture (Consejo de Dentistas, Organización Colegial de Dentistas de España, 2020).

-When finished, collect material to be sterilized, take off the PPE and use the marked exit route.

- Avoid direct contact with the patients when they enter and leave (Izzetti et al.).

- Once the clinical session is finished, all non-reusable material should be discarded in a type III waste container with a lid.
Aerate the common spaces regularly and both at the beginning and at the end of the day. Work is only to be performed in areas where there is the possibility of opening windows to ventilate.

- It is important that students comply responsibly with the teaching, clinical and travel instructions for the center.

b) Patient management: Patient shedulling and telephone triage. Patient scheduling will depend on the prevailing epidemiological situation or phase. The incorporation of telemedicine means video consultation will be a new way of communicating, and the student must be prepared accordingly and acquire this new competence in order to manage the processes via telephone or video call with the patient.

Much attention should be paid to the patient's medical history, thoroughly reviewing it, completely filling in the history data (general and dental health) and establishing the importance of a good telephone triage to ascertain the individual risk of the patient, the reason for consultation and the possibility of a remote resolution of their problem. Also to make an appointment with enough time, explain the rules (Yang et al., 2020).

The incorporation of an online consultation service will be very necessary at this time in which telemedicine has helped and will help to solve many processes (Peditto et al.; Song et al., 2020; Wu \& Chang, 2020). It is very important to implement this system when dealing with vulnerable and fragile patients (Government of the United Kingdom, 2020a). When scheduling appointments, the patient's systemic status will have to be taken into account, programming the treatment of those most fragile/vulnerable early in the morning, moment of least risk of aerosols in the environment (Dental Schools Council; Ge et al.). In addition, care must be taken that these patients do not coincide with others.

Telephone triage will always include key questions to guide us about the possibility of the patient presenting COVID-19 (Nanda \& Nanda, 2020). Of course, the patient who presents symptoms or has a positive diagnosis of SARS-CoV-2 infection will be instructed to stay at home and informed that they can be safely treated after complying with the protocols established by the Ministry of Health of Spain (Ministerio de Sanidad, Gobierno de España, 2020). The students will only be able to attend to patients who are COVID-19 negative, applying the 
screening and temperature taking parameters currently in force (Dental Schools Council).

c) Organization of work in the clinical area: The following procedures (Consejo de Dentistas, Organización Colegial de Dentistas de España) will be applied: at the beginning of the day, during each clinical session (before, during, after patient care) and at the end of the day.

Clinical work: Table I differentiates the types of treatments according to low or high generation of aerosols, (LAGPs/HAGPs) including the decontamination processes of instruments with the recommendation of the appropriate PPE (personal protective equipment), as well as considerations in the clinical work (Government of the United Kingdom 2020b; Mateos Moreno et al., 2020; Ministerio de Sanidad, Gobierno de España; National Health Service; Terán et al., 2020; Rodríguez et al., 2020). It is very important that staff and students know the appropriate sequence for PPE donning and doffing according to the type of treatment to be performed on the patient (Centers for Disease Control and Prevention, 2020; Mateos Moreno et al.; National Health Service; Rodríguez et al.; World Health Organization, 2020a).

\section{d) Instrument cleaning circuit:}

- Removal of the used instruments in a dirty tray to start the usual sterilization chain in the cleaning and sterilization room. Adequate PPE.

- Insist on minimizing production of jet wash aerosols.

Disinfection of critical (Balaji, 2020; Consejo de Dentistas, Organización Colegial de Dentistas de España; Liang, 2020; Ge et al., 2020) including dental chair, lamp, suction system, chairs, furniture, computer and floors (Henwood; Peng et al.) will be carried out with cleaning products with proven viricidal capacity (Standard EN 14476) or with a sodium hypochlorite solution at $0.1 \%$ by applying it with a disposable cloth or sprayers, leaving it to act for at least 1 minute. Cleaning personnel in critical areas must use PPE with the same level of protection as that used in clinical work (Molina \& García, 2020; Peng et al.).

\section{e) Necessary measures to reduce viral transmission by air at the School of Dentistry.}

- Ventilation and air conditioning: Ventilation (which can be natural, mechanical, or hybrid / mixed) (World Health Organization, 2020) can effectively dilute the concentration of SARS-CoV-2 in ambient air (Liu et

Table I. PPE and recommended considerations according to the type of dental procedure: LAGPs vs HAGPs, Adapted from: Mateos Moreno et al., 2020; National Health Service, 2020; Rodríguez et al., 2020; Terán et al., 2020; Ministerio España, 2020.

\begin{tabular}{|c|c|c|}
\hline LOW AEROSOL GENERATING PROCEDURES (LAGPS) & PPE & CONSIDERATIONS \\
\hline $\begin{array}{l}\text { - Remote consultations } \\
\text { Oral exam (without using triple syringe), periodontal probing } \\
\text { - Preventive and self-care measures, hygiene instructions. } \\
\text { - Take X-rays, impressions, (patients without reflux) } \\
\text { - Fluo ride application and other remineralizers, (does not } \\
\text { exclude possibility of droplets if coughing, nausea) } \\
\text { - Simple extractions } \\
\text { - Use of manual instruments (caries removal with a spoon, } \\
\text { periodontal treatment with curettes) } \\
\text { - Orthodontic treatment (appliance adjustments) }\end{array}$ & $\begin{array}{ll}> & \text { Gloves } \\
> & \text { Disposable gown or apron } \\
& \text { FFP2 } \\
& \text { Universal protection glasses (anti- } \\
\text { splash) } & \\
& \text { Optional: } \\
& \text { Facial screen } \\
& \text { Second pair of gloves } \\
& \text { Cap } t,\end{array}$ & $\begin{array}{l}\text {-Patient with mask during face } \\
\text { to face anamnesis } \\
\text {-Preoperative mouthwash } \\
\text {-Aspiration with saliva ejector } \\
\text {-Work four-handedly } \\
\text {-Ventilation 5-15 minutest }\end{array}$ \\
\hline HIGH AEROSOL GENERATING PROCEDURES (HAGPS) & PPE & CONSIDERATIONS \\
\hline $\begin{array}{l}\text { - Use of triple syringe (No consensus) ††, } \\
\text {-washing, drying, etching essential in m ultiple treatments: } \\
\text { conservative, prosthetics...) } \\
\text { - Ultrasonic or other mechanized scalers (tartrectomy) } \\
\text { Treatments that require compressed air with rotating } \\
\text { instruments at high speed handpieces: } \\
\text {-surgical extraction, odontosection or osteotomy, rutine restorative } \\
\text { procedures, carvings, removing cement of attaches or brackets, } \\
\text { endodontic openings ... } \\
\text { - Jet wash the instruments. } \\
\text { - Decontamination in ultrasound tray }\end{array}$ & $\begin{array}{ll}> & \text { Gloves } \\
> & \text { Waterproof gown with adjustable cuff } \\
& \text { Cap } \mathrm{t}, \\
> & \text { FFP3 or alternatively FFP2 } \\
> & \text { IIR (Fluid Resistant) Surgical Mask } \\
& \text { over FFP2 } \\
>\quad \text { Integral protection glasses (waterproof) } \\
\text { field } 5 \text { in frame } \\
\text { Optional: } \\
>\quad \text { Facial screen, } \\
>\quad \text { Second pair of gloves } \\
>\quad \text { Leggings } t \text {. }\end{array}$ & $\begin{array}{l}\text {-Patient with mask during face } \\
\text { to face anamnesis } \\
\text {-Preoperative mouthwash } \\
\text {-High volume aspiration HVE } \\
\text { with saliva ejector turned off } \\
\text {-Rubber dam } \\
\text {-Work with four hands } \\
\text {-Door closed } \\
\text {-15-50 minute ventilation } \dagger \\
\text { - Do not remove the } \\
\text { respiratory or eye } \\
\text { protection in the clinical } \\
\text { space. }\end{array}$ \\
\hline
\end{tabular}

†, Depending on the authors consulted. ††Washing and drying (separately, with low pressure, without spray and with HVE simultaneously) is not considered an AGP, for that reason, sealants and placing restoration material is consider a LAGP. Still not consensus. 
al., 2020). It is very useful to measure CO2 concentration in the air to know if it is within healthy parameters or if we need to increase the ventilation. The minimum time necessary for natural ventilation between patients after procedures that do not generate aerosols will be from 5 (Izzetti et al.) to 15 minutes (Cochrane Oral Health, 2020). On the other hand, after aerosol generating procedures, it would be necessary to ventilate at least 15-60 minutes (European Centre for Disease Prevention and Control, 2020; National Health Service; Public Health Ontario, 2020; Qian et al. 2010).

Regarding the air conditioning systems of buildings, they should not be turned off as a measure to prevent the spread of SARS-CoV-2 (American Society of Heating, Refrigerating and A-C Engineers, 2020) but these systems require regular maintenance (Leggat \& Kedjarune, 2001). In order to prevent the spread of polluted air to other rooms, recirculation in centralized air conditioning systems should be cancelled (Federation of European Heating, Ventilation and Air Conditioning Associations, 2020). In multisplit type air conditioners or individual splits, it would not be necessary to cancel recirculation (Tapias et al., 2020).

Placement of HEPA filters and ultraviolet light chambers in the ducts would be positive to promote air decontamination (Veena et al., 2015).

- Air purification (ultraviolet light, HEPA/ULPA filters). In a clinic with adequate natural ventilation, if a procedure has been performed in which aerosols have been generated, irradiation with $\mathrm{C}$-spectrum ultraviolet (UV) light is recommended before aeration, and once the patient and professional have left the room. The power ranges are close to $180 \mathrm{~W}$ and allow to sterilize the air in approximately 6 minutes for an aerosolized area of around 8 square meters. For larger spaces, the time or power requirements will be greater. The devices should ideally be close to the aerosol production source, which is non-directional. Subsequently it will be necessary to clean and disinfect the surfaces (Tapias et al.).

In closed spaces with inadequate natural ventilation, if no other type of ventilation is available the presence of air purifiers may be necessary. New guidelines designed by the Occupational Risk Prevention Service will be required, such as the installation of effective air purification devices with HEPA 14 or 15 (Tapias et al.) or ULPA filters (New England Complex Systems Institute, 2020) near the breathing/aerosol emission zone (Asociación Española de Ingeniería Hospitalaria, 2020) though it should not be assumed that they completely eliminate the risk of transmission by air (Dietz et al., 2020).

f) Preventive dentistry. The population's demand for elective treatments can decrease in the face of the economic crisis and the fear of contagion, leading patients to choose a less conservative treatment like a dental extraction. On the other hand, it is also possible that the patient, in order to avoid complications and deterioration in their oral health, is more receptive to follow preventive advice about correct oral hygiene and healthy habits during confinement, so we must take this opportunity to offer advice in preventive dentistry and enhance it.

Our philosophy must lead on non-invasive prevention principles and techniques (biofilm, dietary and mineralization control, based on caries risk assessment) and micro-invasive caries management with a minimized aerosol generation procedures whenever possible (using low-speed, hand excavators, using separate low pressure water/ air streams or wet/ dry cotton wool pledgets...) (National Health Service).

g) Possible future scenarios and action plans. Dental schools should focus on reevaluating and prioritizing their policies and protocols and include a detailed contingency plan that adapts to the changing epidemiological situation. We have to be prepared for there to be a phase of severe confinement again in this new wave. In that case, mobility of people will have to be reduced and only emergencies will be attended, with appointments on the same day and prioritizing according to the type of emergency: INFLAMMATION -INFECTION-TRAUMA- BLEEDING-PAIN (American Dental Association, 2020). Non-delayable processes will be: presumptive cancerous / precancerous lesions and dental conditions resulting in acute and severe systemic disease.

HAGPs should be avoided where possible while there is sustained community transmission.

\section{CONCLUSIONS}

- It is critical that research provides solutions for the effective prevention of COVID-19.

- Health promotion and preventive and minimally invasive dentistry and public health become even 
more important during pandemic. Students must receive additional training in preventing the transmission of infectious diseases.

- Having established specific protocols in place to control the transmission of the new coronavirus according to the risk of the activity and assigning well-defined responsibilities will decrease anxiety and help towards the physical and psychological well-being of students, faculty and other staff.

- Technological development enables remote or telephone monitoring, increasing control options. The student must demonstrate their competences in this matter.

- Self-care and patient education, assuming responsibility for their oral and general health, will provide additional added value to the previous measures.

- The international collaboration among universities is essential to redefine dental studies and adapt them to the current epidemiological situation, and dental schools must be prepared for this new wave and other future epidemics.

LENGUAS, S. A. L.; MATEOS, M. M. V.; GARCÍA, V. G.; LAMAS, O. M.; MARTÍN, M. J. F.; VALDEPEÑAS, M. J. \& GARCILLÁN, I. M. R. Protocolos anti covid-19 en la educación clínica de odontología durante la segunda ola. Int. J. Odontostomat., 15(1):59-66, 2021.

RESUMEN: Esta segunda oleada de la pandemia COVID-19 ha llevado al desarrollo de estrategias para garantizar la docencia clínica en las facultades de odontología y adaptarla a esta nueva situación epidemiológica protegiendo la salud de todo el personal, estudiantes, pacientes y acompañantes. Revisamos un total de 51 documentos, incluidos artículos y guías o recomendaciones emitidas por escuelas de odontología, sociedades científicas y otras instituciones, con el fin de hacer un balance de la evidencia actual disponible sobre el impacto de la pandemia de COVID19 en las escuelas de odontología. Describimos una serie de medidas a implementar en áreas semicríticas y críticas de las facultades de odontología para garantizar la seguridad de todos y la continuidad de la formación clínica de los estudiantes. Estos incluyen: circuitos de movilidad, distanciamiento apropiado, programación de pacientes, triaje telefónico, equipos de protección personal, medidas para reducir la transmisión viral por ventilación de aire y varias otras acciones específicas para la generación baja o alta de aerosoles por los tratamientos. Las escuelas de odontología deben estar preparadas e implementar las medidas necesarias de acuerdo al nivel de riesgo de infección durante las actividades presenciales, especialmente en las clínicas, que brindan formación imprescindible e imposible de adquirir en línea. Las escuelas de odontología deben centrarse en priorizar la odontología preventiva y mínimamente invasiva minimizando los procedimientos que generan aerosoles siempre que sea posible. Más que nunca, la cooperación internacional entre universidades para la elaboración de protocolos es fundamental. Estos protocolos deben garantizar la salud de todos en esta nueva segunda ola de la pandemia y en posibles escenarios epidemiológicos futuros.

PALABRAS CLAVES: escuelas de odontología, educación odontológica, prevención, COVID-19, SARSCoV-2.

\section{REFERENCES}

American Dental Association (ADA). Center for Professional Success. Coronavirus (COVID 19) Center for Dentists. Chicago, American Dental Association, 2020. Available from: https://success.ada.org/en/practice-management/patients/ infectious-diseases-2019-novel-coronavirus

American Society of Heating, Refrigerating and A-C Engineers. ASHRAE Position Document on Infectious Aerosols. Atlanta, American Society of Heating, Refrigerating and A-C Engineers, 2020. Available from: https://www.ashrae.org/file\%20library/ about/position\%20documents/pd_infec tiousa erosols_2020.pdf

Asociación Española de Ingeniería Hospitalaria. Recomendaciones de Actuación para Servicios Técnicos en Hospitales Durante la Crisis Sanitaria Ocasionada por el COVID-19. Madrid, Asociación Española de Ingeniería Hospitalaria, 2020. Available from: https://aeih.org/recomendaciones-actuacionservicios-tecnicos-hospitales-covid-19/

Balaji, S. M. COVID-19-Future of dentistry. Indian J. Dent. Res., 31(2):167-8, 2020.

Centers for Disease Control and Prevention (CDC). Using Personal Protective Equipment (PPE). Atlanta, Centers for Disease Control and Prevention, 2020. Available from: https:/ /www.cdc.gov/coronavirus/2019-ncov/hcp/using-ppe.html

Cochran, M. A.; Miller, C. H. \& Sheldrake, M. A. The efficacy of the rubber dam as a barrier to the spread of microorganisms during dental treatment. J. Am. Dent. Assoc., 119(1):141-4, 1989 .

Cochrane Oral Health. Recommendations for the re-opening of dental services: a rapid review of international sources. Web Site. Cochrane.org, 2020. Available from: https:// oralhealth.cochrane.org/news/recommendations-re-openingdental-services-rapid-review-international-sources

Consejo de Dentistas. Organización Colegial de Dentistas de España. Plan Estratégico de Acción para el Periodo Posterior a la Crisis creada por el COVID-19. Madrid, Consejo de Dentistas. Organización Colegial de Dentistas de España, 2020. Available from: https://www.consejodentistas.es/ comunicacion/actualidad-consejo/notas-de-prensa-consejo/ item/1763-pla-estrategico-de-accion-para-el-periodo-posterior-a-la-crisis-creada-por-el-covid-19.html

Dental Schools Council. COVID-19 - Returning to Student-led Dental Clinical Treatments (v.1.1). A Summary of Relevant Literature and the Opportunities to Identify and Manage Risk. June 2020. London, Dental Schools Council, British Dental Association, Association of Dental Hospitals, 2020. Available from: https://www.dentalschoolscouncil.ac.uk/wp-content/ uploads/2020/07/COVID-19-report-on-returning-to-studentled-dental-clinical-treatments-v.1.1.pdf 
Dietz, L.; Horve, P. F.; Coil, D. A.; Fretz, M.; Eisen, J. A. \& Van Den Wymelenberg, K. 2019 Novel Coronavirus (COVID-19) pandemic: built environment considerations to reduce transmission. $m$ Systems, 5(2): e00245-20, 2020.

European Centre for Disease Prevention and Control (ECDC). Disinfection of Environments in Healthcare and NonHealthcare Settings Potentially Contaminated with SARS-CoV2. Solna, European Centre for Disease Prevention and Control, 2020. Available from: https://www.ecdc.europa.eu/en/ publications-data/disinfection-environments-covid-19

Facultad de Odontología, Universidad Complutense de Madrid. Protocolo de Medidas Organizativas y Específicas: Guía de Recomendaciones Preventivas para la Reincorporación en la Facultad de Odontología de la Universidad Complutense de Madrid en Relación a la Potencial Exposición al Sars-Cov2 (v20200601). Madrid, Facultad de Odontología, Universidad Complutense de Madrid, 2020. Available from: https:// odontologia.ucm.es/file/guiareincorporacion

Federation of European Heating, Ventilation and Air Conditioning Associations (REHVA). COVID-19 Guidance Document, April 3, 2020. Web Site, Federation of European Heating, Ventilation and Air Conditioning Associations, 2020. Available from: https:/ /www.rehva.eu/activities/covid-19-guidance

Ge, Z.; Yang L.; Xia, J.; Fu X. \& Zhang, Y. Possible aerosol transmission of Covid-19 and special precautions in dentistry. J. Zhejiang Univ. Sci., 21(5):361-8, 2020.

Government of the United Kingdom. COVID-19: Guidance on Shielding and Protecting People Defined on Medical Grounds as Extremely Vulnerable. London, Government of the United Kingdom, 2020a. Available from: https://www.gov.uk/ government/publications/guidance-on-shielding-andprotecting-extremely-vulnerable-persons-from-covid-19

Government of the United Kingdom. Guidance COVID-19: Personal Protective Equipment Use for NON-Aerosol Generating Procedures. London, Government of the United Kingdom, 2020b. Available from: https://www.gov.uk/government/ publications/covid-19-personal-protective-equipment-use-foraerosol-generating-procedures

Henwood, A. F. Coronavirus disinfection in histopathology. J. Histotechnol., 43(2):102-4, 2020.

Herrera, D.; Serrano, J.; Roldán, S. \& Sanz, M. Is the oral cavity relevant in SARS-CoV-2 pandemic? Clin. Oral Investig., 2020. DOI: https://www.doi.org/10.1007/s00784-020-03413-2

Izzetti, R.; Nisi, M.; Gabriele, M. \& Graziani, F. COVID-19 transmission in dental practice: brief review of preventive measures in Italy. J. Dent. Res., 99(9):1030-8, 2020.

Jacks, M. E. A laboratory comparison of evacuation devices on aerosol reduction. J. Dent. Hyg., 76(3):202-6, 2002.

King, T. B.; Muzzin, K. B.; Berry, C. W. \& Anders, L. M. The effectiveness of an aerosol reduction device for ultrasonic scalers. J. Periodontol., 68(1):45-9, 1997.

Leggat, P. A. \& Kedjarune, U. Bacterial aerosols in the dental clinic: a review. Int. Dent. J., 51(1):39-44, 2001.

Liang, T. Handbook of COVID-19. Prevention and Treatment. Zheijiang, University of Zheijiang, School of Medicine, 2020. Available from: https://www.zju.edu.cn/english/2020/0323/ c19573a1987520/page.htm

Liu, Y.; Ning, Z.; Chen, Y.; Guo, M.; Liu, Y.; Gali, N. K.; Sun, L.; Duan, Y.; Cai, J.; Westerdahl, D.; et al. Aerodynamic analysis of SARS-CoV-2 in two Wuhan hospitals. Nature, 582(7813):557-60, 2020.

Mateos Moreno, M. V.; Lenguas Silva, A. L.; Pastor Ramos, V.; García Ávila, I.; García Vázquez, M. T.; García Vicent, G.; Lamas Oliveira, M.; Rodríguez Alonso, E.; Tapias Perero, V. F.; Terán de Agustín, A. I.; et al. Odontología en entorno
COVID-19. Adaptación de las Unidades de Salud Bucodental en los Centros de Salud de la Comunidad de Madrid. Rev. Esp. Salud Pública, 94:e202011148, 2020.

Meng, L.; Hua, F. \& Bian, Z. Coronavirus Disease 2019 (COVID19): emerging and future challenges for dental and oral medicine. J. Dent. Res., 99(5):481-7, 2020.

Ministerio de Sanidad, Gobierno de España. Procedimiento de Actuación para los Servicios de Prevención de Riesgos Laborales frente a la Exposición al SARS-CoV-2. Madrid, Ministerio de Sanidad, Gobierno de España, 2020. Available from: https://www.google.com/url? sa=t\&source = web\&rct=j\&url=https://www.mscbs.gob.es/profesionales/ saludPublica/ccayes/alertasActual/nCov/documentos/ Proteccion_Trabajadores_SARS-CoV-2.pdf\&ved $=2 \mathrm{ah}$ UKEwiVxKvf3uTsAhUB6RoKHTg-AXoQFjAAegQIA hAB\&usg=AOvVaw3nOi31Lm7p4vuljkX47e-4

Molina, T. R. \& García, Z. O. Manual de Limpieza y Desinfección Hospitalaria. Cali, Comité de Infecciones Intrahospitalarias, HospitalDepartamental Mario Correa Rengifo, 2003. Available from: http://ridsso.com/documentos/muro/207_1578425437_ 5e14dc5d80a7e.pdf

Nanda, K. D. \& Nanda, J. Recommendations and management in dental practice during Corona Virus COVID-19. Open Dent. J., 14:191-3, 2020.

National Health Service (NHS). Standard Operating Procedure. Transition to Recovery. A Phased Transition for Dental Practices Towards the Resumption of the Full Range of Dental Provision. Version 4. London, National Health Service, 2020a. Available from: https://www.england.nhs.uk/ coronavirus/wp-content/uploads/sites/52/2020/06/C0839-dental-recovery-sop-v4.01-29-oct.pdf

New England Complex Systems Institute. Could air filtration reduce COVID-19 severity and spread? Cambridge, New England Complex Systems Institute, 2020. Available from: https://necsi.edu/could-air-filtration-reduce-covid19-severityand-spread

Pastor Ramos, V.; Rodríguez Alonso, E. \& García Ávila, I. Mascarillas y máscaras de protección respiratoria en entorno COVID-19. Cient. Dent., 17(2):147-57, 2020.

Peditto, M.; Scapellato, S.; Marcianò, A.; Costa, P. \& Oteri, G. Dentistry during the COVID-19 Epidemic: An Italian Workflow for the Management of Dental Practice. Int. J. Environ. Res. Public Health, 17(9):3325, 2020.

Peng, X.; Xu, X.; Li, Y.; Cheng, L.; Zhou, X. \& Ren, B. Transmission routes of 2019-nCoV and controls in dental practice. Int. J. Oral Sci., 12:9, 2020.

Prati, C.; Pelliccioni, G. A.; Sambri, V.; Chersoni, S. \& Gandolfi, M. G. COVID-19: its impact on dental schools in Italy, clinical problems in endodontic therapy and general considerations. Int. Endod. J., 53(5):723-5, 2020.

Public Health Ontario. Covid-19 in Dental Cares Settings. Ontario, Public Health Ontario, 2020. Available from: https:// www.publichealthontario.ca/-/media/documents/ncov/ipac/ 2020/07/covid-19-dental-care-settings.pdf?la=en

Rodríguez, E.; García, I.; García, M. T. \& García, G. Elección del equipo de protección individual adecuado frente al virus SARS-CoV-2 en la clínica dental. Maxillaris, 246:47-55, 2020. Available from: https://www.maxillaris.com/maximas20200706-Eleccion-del-equipo-de-proteccion-individual-adecuado-frente-al-virus-SARS-CoV-2-en-la-clinica-dental.aspx

Rothe, C.; Schunk, M.; Sothmann, P.; Bretzel, G.; Froeschl, G.; Wallrauch, C.; Zimmer, T.; Thiel, V.; Janke, C.; Guggemos, W.; et al. Transmission of 2019-nCoV Infection from an Asymptomatic Contact in Germany. N. Engl. J. Med., 382(10):970-1, 2020. 
Song, X.; Liu, X. \& Wang, C. The role of telemedicine during the COVID-19 epidemic in China-experience from Shandong province. Crit. Care, 24(1):178, 2020.

Tag El Din, A. M. \& Ghoname, N. A. H. Efficacy of rubber dam isolation as an infection control procedure in paediatric dentistry. EMHJ East. Mediterr. Health J., 3(3):530-9, 1997.

Tapias, V.; Vivas, C. A.; Valdepeñas, J. \& Mateos, M. V. Desinfección ambiental, sistemas de climatización y su relación con el brote de COVID-19. Maxillaris, 245:64-9, 2020. Available from: https://www.maxillaris.com/maximas-20200529-Desinfeccionambiental-sistemas-de-climatizacion-y-su-relacion-con-el-brotede-COVID-19.aspx

Terán, A. I.; Lenguas, A. L.; Pastor, V. \& Lamas, M. Prevención de la COVID-19: Protección ocular. Recomendaciones para una actividad odontológica segura en la clínica dental. Maxillaris, 245:717, 2020. Available from: https:// www.maxillaris.com/maximas20200603-Prevencion-de-la-COVID-19-Proteccion-ocular-Recomendaciones-para-una-activi-dad-odontologica-segura-en-laclinica-dental.aspx

United States Department of Labor. Occupational Safety and Health Administration COVID-19. Control and Prevention-Dentistry Workers and Employers. Washington DC, United States Department of Labor, 2020. Available from: https://www.osha.gov/ SLTC/covid-19/dentistry.html

University of Glasgow. COVID-19 Campus Managed Plan. May 2020. Version 1. Glasgow, University of Glasgow, 2020. Available from: https://www.gla.ac.uk/media/Media_725323_smxx.pdf

Veena, H. R.; Mahantesha, S.; Joseph, P. A.; Patil, S. R. \& Patil, S. $\mathrm{H}$. Dissemination of aerosol and splatter during ultrasonic scaling: A pilot study. J. Infect. Public Health, 8(3):260-5, 2015.

Whitworth, J. COVID-19: a fast evolving pandemic. Trans. R. Soc. Trop. Med. Hyg., 114(4):241-8, 2020.

World Health Organization. How to put on and take off. Personal Protective Equipment (PPE). Geneva, World Health Organization, 2020. Available from: https://www.who.int/csr/resources/ publications/PPE_EN_A1sl.pdf

Wu, M. \& Chang, Y. C. COVID-19 and its implications in the management of resource infrastructure. J. Dent. Sci.,15(2):2256, 2020.

Xu, H.; Zhong, L.; Deng, J.; Peng, J.; Dan, H.; Zeng, X.; Li, T. \& Chen, Q. High expression of ACE2 receptor of 2019-nCoV on the epithelial cells of oral mucosa. Int. J. Oral. Sci., 12:8, 2020.

Yang, Y.; Zhou, Y.; Liu, Z. \& Tan, J. Health services provision of 48 public tertiary dental hospitals during the COVID-19 epidemic in China. Clin. Oral Investig., 2020. DOI: https://www.doi.org/ $10.1007 / \mathrm{s} 00784-020-03267-8$
Corresponding author:

Ana Leticia Lenguas Silva

Departamento de Especialidades Clínicas Odontológicas Facultad de Odontología

Universidad Complutense de Madrid

Plaza Ramón y Cajal, s/n

Ciudad Universitaria

28040-Madrid

SPAIN

E-mail: alenguas@pdi.ucm.es 